\title{
RESTRUKTURISASI NOMENKLATUR ORGANISASI PERANGKAT DAERAH DI KABUPATEN SINJAI
}

\author{
A.M Azhar Aljurida \\ Fakultas Ilmu Sosial dan Ilmu Politik, UNIVERSITAS INDONESIA TIMUR \\ azhar.aljurida@uit.ac.id
}

\begin{abstract}
ABSTRAK
Pelaksanaan Peraturan Pemerintah Nomor 84 Tahun 2000 dipandang tidak sesuai dengan keadaan dan perkembangan penataan pemerintah daerah sehingga perlu disempurnakan dengan ditetapkannyaPeraturan Pemerintah Nomor 8 Tahun 2016Tentang Perangkat Daerah, restrukturisasi perangkat daerah di Kabupaten Sinjai dilakukan refungsionalisasi untuk memberikan struktur organisasi yang lebih efektif dan efisien, metode yang digunakan dalam penelitian ini adalah penelitian kualitatif dengan pendekatan normatif.Hasil penelitian menunjukkan restrukturisasi yang dilakukan oleh pemerintah Kabupaten Sinjai melalui berbagai tahapan diantaranya, a. urusan pemerintahan yang menjadi kewenangan daerah; b. intensitas urusan pemerintahan dan potensi daerah; c. efisiensi; $d$. efektivitas; e. pembagian habis tugas; f. rentang kendali; g. tata kerja yang jelas; dan h. fleksibilitas. Susunan perangkat daerah ini juga ditetapkan melalui berdasarkan peraturan daerah, setelah mendapatkan persetujuan dari menteridalam negeri.
\end{abstract}

Kata Kunci : Resktrukturisasi, Organisasi dan Perangkat Daerah

\section{Pendahuluan}

Reformasi Birokrasi di Indonesia dapat diartikan sebagai sebuah arah tindakan perubahan atau pembaruan yang berdimensi pada restrukturisasi,revitalisasi, dan refungsionalisasi yang selanjutnya dapat diartikan sebagai tindakan untuk merubah struktur yang dipandang sudah tidak sesuai dengan tuntutan zaman dan dianggap tidak efektif lagi dalam memajukan organisasi. Revitalisasi merupakan upaya untuk memberi tambahan energi atau daya kepada organisasi atau lembaga agar dapat mengoptimalkan kinerja organisasi. Karena itu, revitalisasi akan berkaitan dengan perumusan kembaliuraian tugas, penambahan kewenangan kepada unitunitstrategis, peningkatan alokasi anggaran, penambahan atau penggantian berbagai instrumen pendukung dalam menjalankan tugas-tugas organisasi. Sedangkan refungsionalisasi lebih berkaitan dengan tindakan atau upaya untuk memfungsikan kembali sesuatu yang sebelumnya tidak berfungsi.

Dengan demikian,reformasi pemerintah daerah akan mengarah pada tiga dimensi reformasi tersebut. Sarundajang (2001:123)Reformasi pemerintah daerah itu sendiri dalam pandangan Sarundajang, diperlukan karena beberapa alasan penting, antara lain adalah : Pertama,karena struktur organisasi dan administrasi pemerintah daerah yang ada saat ini dipandang tidak lagi efektif dalam mengemban misinya, terutama jika dikaitkan dengan perkembangan kehidupan masyarakatdan tuntutan globalisasi. Kedua, karena dalam kenyataan sensitifitas pemerintah daerah dalam mencermati perkembangan keadaan sudah mulai lemah dan hal ini diperparah dengan rendahnya kinerja aparaturpemerintah daerah. Ketiga, image masyarakat tentang organisasi pemerintah, termasuk pemerintah daerah sudah semakin jelek yang menyebabkan terjadinya berbagai tuntutan terhadap perubahan dalam 
penyelenggaraan pemerintah

Sarundajang (2001:123).

Adanyakecenderungan

daerah.

untuk

membentuk organisasi perangkat daerah yang terlalu besar dan kurangdidasarkan pada kebutuhan nyata di daerah yang bersangkutan. Berbagai pertimbangan yang digunakan dalam pengambilan keputusan dalam penataan kelembagaan seringkali cenderung lebih bernuansa politik dari pada pertimbangan rasional obyektif, efisiensi dan efektivitas. Oleh karena itu, pelaksanaan Peraturan Pemerintah Nomor 84 Tahun 2000 dipandang tidak sesuai dengan keadaan dan perkembangan penataan pemerintah daerah sehingga perlu disempurnakan dengan ditetapkannya Peraturan Pemerintah Nomor 8 Tahun 2016Tentang Perangkat Daerah.

Kesalahan dalam melakukan inventarisasi dan identifikasi kebutuhan, kemampuan daerah serta keahlian aparatur, menurut pengamatan penulis di lapangan mempengaruhi pola pembentukan dan penyusunan struktur organisasi Sekretariat Daerah sebagai suatu perangkat daerah di Kabupaten Sinjai. Hakikat pelaksanaan kebijakan restrukturisasiyang semula dimaksudkan untuk mengoptimalkan kinerja aparatur dalam memberikan pelayanan kepada masyarakat, pada kenyatannya justru cenderung terfokus pada kebutuhan distribusijabatan dimana keputusan distribusi jabatan inipun lebih banyak dipengaruhi oleh like and dislike tanpa mempertimbangkanlatar belakang pendidikan, serta spesifikasi keahlian aparat yang diberikan jabatannya. Disisi lain masalah yang timbul juga berkaitan dengan urusan pemerintahan misalnya adanya urusan yang mestinya terpisah justru malah disatukan, dilain sisi jumlah jabatan yang berubah yang harus berdampak pada karir pegawai misalnya yang semula eselon II terpaksa harus turun menjadi eselon III, pada jumlah SKPD kabupaten Sinjai tidak melakukan pengurangan tetap berjumlah 33 SKPD, namun yang berubah yaitu pada nomenklatur status lembaga atau kantor yang digabung, misalnya SKPD yang mencolok berubah yaitu pada Dinas
Komunikasi, Informatika, Statistik dan Persandian semula dinas ini hanya ada dua nomenklatur yaitu Dinas Komunikasi dan Informatika, perubahan mencolok juga pada Dinas tata ruang dan pemukinan berubah nomenklatur menjadi Dinas Perumahan, Kawasan Permukiman dan Pertanahan (Sumber: portal info publik 30/9/2016).

Berbagai aspek dalam struktur, yang dalam pengamatan awal penulis nampak turut mempengaruhi kinerja organisasi di lingkungan sekretariat daerah Kabupaten Sinjai antara lain adalah masih lemahnya formalisasi baik menyangkut tugas, mekanisme kerja maupun output yang harus dijalankan setiap unit ataupun individu dalam organisasi. Aspek lainnya juga berdampak pada melebarnya rentang kendali (span of control) yang menimbulkan masalah "inkoherensi institusional”, karena fungsi yang seharusnya ditangani oleh satu kesatuan unit harus diderivasi ke beberapa unit organisasi, sehingga pada akhirnya mengarah pada proliferasi birokrasi.

Atas dasar latar belakang sebagaimana diungkapkan sebelumnya, maka penulis terdorong untuk melakukan penelitian mengenai Analisis Restrukturisasi Nomenklatur Organisasi Perangkat Daerah di Kabupaten Sinjai.

\section{Permasalahan}

Pada awal tahun 2017, pemerintah pusat kembali merombak organisasi perangkat daerah dengan pemberlakuan efektif Peraturan Pemerintah Nomor 8 Tahun 2016Tentang Perangkat Daerah, dimana setiap daerah di Indonesia termasuk Kabupaten Sinjai diwajibkan untuk menyusun ulang SKPDnya bersama DPRD dengan membentuk peraturan daerah tentang organisasi perangkat daerah, dengan tetap berdasar pada peraturan tersebut, perubahan yang terkesan sangat dipaksakan ini menimbulkan kekacauan dalam penyelenggaraan pemerintahan daerah termasuk dari segi rentan waktu yang diberikan oleh daerah untuk segera merealisasikan nomenklatur yang baru, beberapa permasalahan juga muncul diantaranya 
penataan kelembagaan lebih bernuansa politik dari pada pertimbangan rasional, obyektif, efisiensi dan efektivitas. Dalam kebijakan ini juga restrukturisasi, masih terdapat kelemahan yang dipengaruhi oleh kesalahan dalam melakukan inventarisasi dan identifikasi kebutuhan unit-unit organisasi yang disesuaikan dengan kebutuhan organisasi dan masyarakat, olehnya itu masalah dalam penelitian ini ditujukan pada bagamaina restrukturisasi yang diterapkan dalam menyusun nomenklatur organisasi perangkat daerah dalam kajian teori Bennis and Mische (2000).

\section{Kajian Teoritis}

\section{Konsep Restrukturisasi}

Perubahan struktur organisasi adalah perubahan yang dilakukan terhadap sebagian ataupun secara keseluruhan struktur organisasi dalam rangka mencari bentuk yang lebih sesuai dengan kebutuhan dan kemapuan organisasi atau dikenal dengan restrukturisasi organisasi.

Menurut Sedarmayanti (2000:60) mengemukakan bahwa upaya restrukturisasi dalam suatu organisasi dapat dilakukan melalui upaya manajemen dengan cara melakukan penataan ulang atau rekayasa ulang (reengineering) sehingga perusahaan dapat melakukan adaptasi terhadap pengaruh perubahan lingkungannya, sehingga perusahan akan tetap bertahan hidup.Dalam kaitan ini, Bennis dan Mische dalam Sedarmayanti (2000:61) mengemukakan arti rekayasa ulang yaitu sebagai berikut :

Rekayasa ulang adalah menata ulangperusahan dengan menantang doktrin, praktek, dan aktivitas yang ada, kemudian secara inovatif menyebarkan kembali modal dan sumber daya manusianya kedalam proses lintas fungsi. Penataan ulang ini dimaksudkan untuk mengoptimalkan posisi bersaing organisasi, nilainya bagi pemegang saham, dan kontribusinya bagi masyarakat.

Disamping itu Hammer dan Champy (1995:27) memberikan batasan reengineering sebagai berikut :
"Reengineering is the fundamental rethinking and radical redesign of business to achieve dramatic improvements in critical, contemporary of performance, such as cost, quality, service, and speed" (Penataan ulang adalah pemikiran ulang secara fundamental dan perancangan ulang secara radikal atas prosesproses bisnis untuk mendapatkan perbaikan dramatis dalam hal ukuran-ukuran kinerja yang penting dan kontemporer, seperti biaya, kualitas, pelayanan dan kecepatan).

Dari definisi tersebut, terdapat 4 (empat) kata kunci yaitu : fundamental, radical, dramatic, proceses. Kata kunci pertama fundamental, mengandung arti bahwa perubahan yang dilakukan dalam organisasi bisnis (atau organisasi apapun, termasuk pemerintahan) harus dilakukan terhadap halhal yang bersifat mendasar, misalnya; visi, misi, tujuan organisasi, aturan yang mendasari beroperasinya orgainsasi dan lainnya. Sedangkan kata kunci kedua radical, mengandung arti bahwa proses perekayasa ulang organisasi harus mengenai akar permasalahannya. Kemudian dengan kata kunci ketiga dramatic,reengineering the cooperation tidak dimaksudkan untuk menghasilkan perubahan yang sifatnya marjinal atau bertahap, sebaliknya justru menghasilkan perubahan yang sifatnya merupakan terebosan baru yang berorientasi ke masa depan. Kata kunci keempat proceses, harus berorientasi pada proses kerja suatu organisasi, tidak berorientasi kepada tugas, pekerjaan, orang maupun struktur organisasi. Proses ini artinya adalah sekumpulan kegiatan yang membutuhkan satu atau beberapa jenis masukan untuk menghasilkan keluaran yang memiliki nilai tambah bagi pelanggan.

Maka berikut ini Bennis dan Mische dalam Sedarmayanti (2000:67) mengajukan lima langkah restrukturisasi, yaitu :

1. Menciptakan visi dan menetapkan tujuan;

2. Mengupayakan bench-marking dan mendifinisikan keberhasilan;

3. Menginovasi proses;

4. Mentransformasikan organisasi, serta 


\section{Volume 1 No 1, Maret 2019}

\section{Memantau proses yang direstrukturisasi. \\ Perampingan organisasi pemda tentunya membawa implikasi pada} terspesialisasinya tugas-tugas pemerintah daerah dan sangat membantu bagi kelancaran pelaksanaan tugas-tugas pemerintahan, pembangunan dan pembinaan masyarakat. Dalam hubungan ini tentunya diperlukan aparatur pemerintah yang benar-benar profesional dalam bidangnya. Karena itu, perampingan organisasi harus diikuti dengan kebijakan pengkondisian aparatur melalui berbagai lembaga pendidikan, baik pendidikan formal maupun pendidikan keterampilan, sehingga diharapkan upaya tersebut akan membentuk kesiapan aparatur dalam menghadapi tantangan abad 21 yang semakin besar. Sarundajang (2000:219).

Dari berbagai pendapat di atas, bila dikaitkan dengan perampinganmaka perampinganbirokrasi merupakan perubahan yang terjadi pada struktur birokrasi yang kompleks menjadi sederhana. Ini berarti penyederhanaan pola wewenang, saluran dan jaringan informasi, jenjang hirarki, rentang kendali, hubungan kerja, prosedur dan tata kerja. Dengan demikian perampingan struktur organisasi birokrasi dapat mempermudah dan mempercepat pemberian laporan, perintah, wewenang dan tanggung jawab, sehingga pekerjaan dapat selesai dengan efektif dan efisiensi dan pada akhirnya dapat mempengaruhi hasil kerja.

Sejalan dengan pendapat Thoha (1991:114) bahwa usaha merampingkan birokrasi yang terlalu gemuk dengan harapan agar tidak lamban dan dapat lebih gesit bergerak, sebenarnya di lihat dari prespektif weberian merupakan usaha mencapai rasional dan efisiensi kerja. Selanjutnya perampingan struktur birokrasi dapat dikatakan berhasil apabila diikuti oleh perubahan prilaku manusia/pegawai yang ada dalam organisasi tersebut.

LAN RI (1998:25) menambahkan dalam rangka analisis, struktur organisasi perlu dibagi dalam unsur-unsurnya yaitu : a. Spesialisasi kegiatan-kegiatan ; ini berkaitan dengan spesialisasi, baik tugas individu maupuntugas kelompok dalam organisasi (pembagian kerja) dan mengelompokkan tugas-tugas tersebut kedalam unit kerja (departemenisasi)

b. Standarisasi kegiatan-kegiatan ; ini berkaitan dengan standarisasi tata kerja, prosedur kerja dan sistem kerja yang digunakan dalam organisasi. Banyak sistem dan prosedur kerja, termasuk didalamnya bentuk organisasi dan bagan organisasi, yang dikembangkan melalui peraturanperaturan tentang kegiatan-kegiatan dan hubungan-hubungan kerja yang ada dalam organisasi atau dapat pula dimasukkan ke dalam manual organisasi.

c. Koordinasi kegiatan-kegiatan ; ini berkaitan dengan pengintegrasian fungsi-fungsi dan unit-unit dalam organisasi yang saling berkaitan dan saling ketergantungan.

d. Sentralisasi dan desentralisasi ; ini berkaitan dengan letak pengambilan keputusan. Dalam struktur organisasi yang disentralisasikan, pengambilan keputusan dilakukan oleh para top manager saja. Dalam desentralisasi, kekuasaan pengambil keputusan didelegasikan kepada individu-individu pada tingkat-tingkat manajemen menengah dan manajemen bawah.

Organisasi seperti itu mempunyai hierarki yang sangat tajam, deskripsi pekerjaan yang rinci dan penekanan yang kuat pada spesialisasi fungsional. Pengendalian tingkat tinggi atas aktivitas pegawai mudah dicapai dengan mengorbankan fleksibilitas.

\section{Konsep Organisasi}

Pengertian organisasi sekarang ini telah bergeser dari pengertian organisasi yang sesungguhnya. Pengertian sederhana organisasi adalah suatu kerja sama kelompok orang untuk mencapai tujuan bersama yang diinginkan dan mau terlibat dengan peraturan yang ada. 
Pengertian sederhana tersebut telah bergeser, pada masa sekarang organisasi lebih dikenal sebagai suatu wadah atau tempat untuk melakukan kegiatan bersama, agar dapat mencapai tujuan yang telah ditetapkan bersama. Ciri-ciri utama dari organisasi berdasarkan pengertian sederhana tersebut adalah:

1. Terdiri dari dua orang atau lebih

2. Ada kerja sama

3. Ada komunikasi antar satu anggotadengan yang

4. Ada tujuan yang ingin dicapai.

Untuk memahami secara lebih jelas, berikut ini disajikan berbagai defenisi mengenai organisasi (Cahayani, 2003:2-3) sebagai berikut:

1. Malinowski mengatakan organisasi sebagai suatu kelompok orang yang bersatu dalam tugas-tugas, terikat pada lingkungan tersebut, menggunakan alat teknologi dan patuh pada peraturan.

2. James D. Mooney mengatakan bahwa organisasi timbul bilamana orang-orang yang bergabung di dalam suatu usaha mencapai tujuan bersama.

3. Chester I. Barnard mengatakan bahwa organisasi ada bila orang-orang berhubungan satu sama lain, mau bekerja sama untuk mencapai tujuan bersama.

4. Henry L. Sisk memandang organisasi sebagai suatu kesatuan, yaitu sekelompok orang yang terlibat bersama-sama di dalam hubungan yang resmi untuk mencapai tujuan-tujuan.

Organisasi menurut Dimock (Suradinata, 1996:26) didefinisikan sebagai berikut :

"Organization is the sistematic bringing together of interpendent part to form a unifield whole throught which authority coordination and control may be exercised to achieve a given purpose."(organisasi diartikan sebagai perpaduan secara sistematis dari bagian-bagian yang saling tergantung/berkaitanuntuk membentuk suatu kesatuan yang bulat melalui wewenang, koordinasi dan pengawasan dalam usaha mencapai tujuan yang telah di tentukan).

Thomson dan Thoha (Supriatna, 2001:133) mengartikan organisasi sebagai berikut:

"An organization is a highly rationalized and impersonal integration of a large specialist coorporating to acieve some announced specific objective"(Suatu organisasi adalah suatu integrasi dari sejumlah spesialis-spesialis yang bekerja sama sangat rasinal dan impersonal untuk mencapai tujuan spesifik yang telah diumumkan sebelumnya.

Sedangkan Chester Barnard (Thoha, 2002:126) merumuskan organisasi sebagai berikut : "An organization is a sistem of consciously coordinared personal activities or forces of two or more person" (suatu organisasi adalah suatu sistem aktivita-aktivita orang yang terkooerdinasikan secara sadar atau kekuatankekuatan yang terdiri dari dua orang atau lebih).

Cara untuk mengubah struktur organisasi yang kaku menjadi struktur organisasi yang memungkinkan untuk melakukan adaptasi adalah dengan meninggalkan seluruh model organisasi pada abad yang silam, bersama dengan semua pengandaian yang mendasarinya. Beberapa pengertian organisasi yang dirumuskan oleh para pakar (dalam Sedarmayanti, 2000:19), diantaranya adalah:

1. Organisasi merupakan suatu pola kerja sama antara orang-orang yang terlibat dalam kegiatan-kegiatan yang saling berhubungan untuk mencapai tujuan tertentu. Wexley dan Yulk.

2. Organisasi adalah struktur hubungan kekuasaan dan kebiasaan orang-orang dalam suatu sistem administrasi. Waldo (1955:6).

3. Organisasi formal adalah suatu sistem kegiatan yang dikoordinasikan secara terus menerus atau kekuatan dari dua orang atau lebih. Bernard (1983:73).

4. Organisasi adalah suatu kesatuan (entity) sosial yang dikoordinasikan secara sadar, dengan sebuah batasan 
yang relatif dapat diidentifikasikan, yang bekerja atasdasar relatif terus menerus untuk mencapai suatu tujuan bersama atau sekelompok tujuan. Robbins (1994:4).

Organisasi sebagai suatu kesatuan sosial dari kelompok manusia, yang saling berinteraksi menurut suatu pola tertentu sehingga setiap anggota organisasi memiliki fungsi dan tugasnya masing-masing, yang sebagai suatu kesatuan mempunyai tujuan tertentu dan mempunyai batas-batas yang jelas, sehingga biasa dipisahkan secara tegas dari lingkungannya. Lubis dan Huseini (1987:1).

\section{Tinjauan Tentang Nomenklatur Organisasi Perangkat Daerah}

Pengertian organisasi sekarang ini telah bergeser dari pengertian organisasi yang sesungguhnya. Pengertian sederhana organisasi adalah suatu kerja sama kelompok orang untuk mencapai tujuan bersama yang diinginkan dan mau terlibat dengan peraturan yang ada. Pengertian sederhana tersebut telah bergeser, pada masa sekarang organisasi lebih dikenal sebagai suatu wadah atau tempat untuk melakukan kegiatan bersama, agar dapat mencapai tujuan yang telah ditetapkan bersama. Ciri-ciri utama dari organisasi berdasarkan pengertian sederhana tersebut adalah:

1. Terdiri dari dua orang atau lebih

2. Ada kerja sama

3. Ada komunikasi antar satu anggota dengan yang

4. Ada tujuan yang ingin dicapai.

Untuk memahami secara lebih jelas, berikut ini disajikan berbagai defenisi mengenai organisasi (Cahayani, 2003:2-3) sebagai berikut:

1. Malinowski mengatakan organisasi sebagai suatu kelompok orang yang bersatu dalam tugas-tugas, terikat pada lingkungan tersebut, menggunakan alat teknologi dan patuh pada peraturan.

4. James D. Mooney mengatakan bahwa organisasi timbul bilamana orang-orang yang bergabung di dalam suatu usaha mencapai tujuan bersama.

5. Chester I. Barnard mengatakan bahwa organisasi ada bila orang-orang berhubungan satu sama lain, mau bekerja sama untuk mencapai tujuan bersama.

6. Henry L. Sisk memandang organisasi sebagai suatu kesatuan, yaitu sekelompok orang yang terlibat bersama-sama di dalam hubungan yang resmi untuk mencapai tujuan-tujuan.

Organisasi menurut Dimock (Suradinata, 1996:26) didefinisikan sebagai berikut :

"Organization is the sistematic bringing together of interpendent part to form a unifield whole throught which authority coordination and control may be exercised to achieve a given purpose."(organisasi diartikan sebagai perpaduan secara sistematis dari bagian-bagian yang saling tergantung/berkaitan untuk membentuk suatu kesatuan yang bulat melalui wewenang, koordinasi dan pengawasan dalam usaha mencapai tujuan yang telah di tentukan).

Thomson dan Thoha (Supriatna, 2001 : 133) mengartikan organisasi sebagai berikut:

"An organization is a highly rationalized and impersonal integration of a large specialist coorporating to acieve some announced specific objective"(Suatu organisasi adalah suatu integrasi dari sejumlah spesialis-spesialis yang bekerja sama sangat rasinal dan impersonal untuk mencapai tujuan spesifik yang telah diumumkan sebelumnya.

Sedangkan Chester Barnard (Thoha, 2002:126) merumuskan organisasi sebagai berikut : "An organization is a sistem of consciously coordinared personal activities or forces of two or more person" (suatu organisasi adalah suatu sistem aktivita-aktivita orang yang terkooerdinasikan secara sadar atau kekuatankekuatan yang terdiri dari dua orang atau lebih). 
Cara untuk mengubah struktur organisasi yang kaku menjadi struktur organisasi yang memungkinkan untuk melakukan adaptasi adalah dengan meninggalkan seluruh model organisasi pada abad yang silam, bersama dengan semua pengandaian yang mendasarinya.

Berikut adalah beberapa pengertian organisasi yang dirumuskan oleh para pakar (dalam Sedarmayanti, 2000:19), diantaranya adalah:

1. Organisasi merupakan suatu pola kerja sama antara orang-orang yang terlibat dalam kegiatan-kegiatan yang saling berhubungan untuk mencapai tujuan tertentu. Wexley dan Yulk.

2. Organisasi adalah struktur hubungan kekuasaan dan kebiasaan orang-orang dalam suatu sistem administrasi. Waldo (1955:6).

3. Organisasi formal adalah suatu sistem kegiatan yang dikoordinasikan secara terus menerus atau kekuatan dari dua orang atau lebih. Bernard (1983:73).

4. Organisasi adalah suatu kesatuan (entity) social yang dikoordinasikan secara sadar, dengan sebuah batasan yang relatif dapat diidentifikasikan, yang bekerja atasdasar relatif terus menerus untuk mencapai suatu tujuan bersama atau sekelompok tujuan. Robbins (1994:4).

Organisasi sebagai suatu kesatuan sosial dari kelompok manusia, yang saling berinteraksi menurut suatu pola tertentu sehingga setiap anggota organisasi memiliki fungsi dan tugasnya masing-masing, yang sebagai suatu kesatuan mempunyai tujuan tertentu dan mempunyai batas-batas yang jelas, sehingga biasa dipisahkan secara tegas dari lingkungannya. Lubis dan Huseini (1987:1).

\section{Metode Penelitian}

Penelitian ini merupakan penelitian kualitatif dengan pendekatan normatif untuk menjelaskan fenomena yang sedang terjadi dalam strukturisasi nomenklatur organisasi perangkat daerah dikabupaten sinjai, peneltian ini berupaya untuk mengungkapkan fakta-fakta lalu kemudian dianalisis menggunakan pendekatan teori dan peraturan pemerintah yang menjelaskan tentang kondisi ideal penataan nomenklatur organisasi.

\section{Hasil Penelitian}

\section{A. Struktur Organisasi Perangkat Daerah di Kabupaten Sinjai}

Sesuai dengan Peraturan Pemerintah Nomor 18 Tahun 2016 Tentang Perangkat daerah, maka prinsip Penyusunan Organisasi Perangkat Daerah mempertimbangkan hal-hal berikut : (1) Kewenangan pemerintah yang dimiliki daerah (2) Karakteristik, potensi dan kebutuhan daerah (3) Kemampuan keuangan daerah (4) Ketersediaan Sumberdaya manusia (5) Pengembangan pola kerja sama antar daerah.

Dengan dasar peraturan diatas, maka daerah diberikan keleluasaan untuk menata organisasi perangkat daerah, dalam rangka pelaksanaan otonomi yang luas, nyata, dan bertanggung jawab. Kedepan, penyusunan organisasi ini dapat berupa unifikasi (penggabungan), destruktifisasi (penghapusan), revitalisasi (mempertegas), efisiensi, span of control (pengendalian), orientasi teknologi dan manusia. Sebagai implikasi diberlakukannya otonomi daerah, maka bertambahlah beban tugas akibat dari penyerahan 11 (sebelas) kewenangan wajib, sehingga konsekuensinya adalah akan terjadinya perubahan-perubahan pada tubuh perangkat daerah Kabupaten Sinjai. Karenanya struktur organisasi harus disesuaikan dengan beban tugas yang ada.Selanjutnya mau tidak mau Pemerintah Kabupaten Sinjai harus melakukan restrukturisasi satuan-satuan organisasi pemerintahan.

Restrukturisasi organisasi Pemerintah Kabupaten Sinjai tersebut memerlukan kebijakan yang tepat dalam penyesuaianpenyesuaian dari perubahan yang terjadi.Kebijakan yang diambil memerlukan pertimbangan yang matang agar nantinya dapat menghasilkan organisasi yang mampu 
memecahkan berbagai persoalan dan dapat mengakomodasi berbagai kepentingan.Karena pada hakekatnya organisasi pemerintah daerah yang baik dalam arti mampu mewadahi pelaksanaan pembangunan dan pelayan terhadap masyarakat memang merupakan faktor penentu dalam pelaksanaan otonomi daerah. Hal ini sejalan dengan apa yang dikatakan oleh Riwu Kaho (1988:256) bahwa salah satu faktor yang paling menentukan apakah suatu daerah dapat/mampu menyelenggarakan urusan rumah tangganya dengan baik atau tidak adalah organisasi pemerintahan daerah itu sendiri. Dalam arti daerah dapat mengatur dan mengurus rumah tangganya sendiri maka diperlukan adanya organisasi (kelembagaan) yang baik pula.

Untuk mendapatkan suatu bentuk kelembagaan (organisasi) yang memadai maka beberapa Dinas, Cabang Dinas, Kantor, Sekertariat serta unit kerja lainnya yang ada di Pemerintahan Kabupaten Sinjai diinventarisasi, didiagnosis dan dianalisis serta disusun kembali berdasarkan tingkat urgensi masingmasing lembaga dan pengelompokan tugas, fungsi-fungsi lembaga sejenis agar dapat dihindari duplikasi dan ketidakjelasan tanggungjawab serta pemborosan-pemborosan penggunaan sumber daya, yang mana hal ini dilakukan dalam rangka penyesuaian dan pengembangan struktur organisasi atau kelembagaan yang sesuai dengan visi, misi dan strategi serta tujuan sasaran organisasi yang ingin dicapai PemerintahanKabupaten Sinjai.

Restrukturisasi yang terjadi pada struktur organisasi Pemerintah Kabupaten Sinjai dapat terlihat dalam tabel sebagai berikut:

Tabel 1

Perubahan Dinas / Badan dan Kantor dilingkunganPemerintah Kabupaten Sinjai.

\begin{tabular}{|c|c|}
\hline $\begin{array}{c}\text { Peraturan Pemerintah Nomor } 41 \\
\text { Tahun } 2007\end{array}$ & $\begin{array}{c}\text { Peraturan } \\
\text { Pemerintah } \\
\text { Nomor } 18 \text { Tahun } \\
2016\end{array}$ \\
\hline $\begin{array}{ll}\text { 1. } & \text { Sekretariat Kabupaten } \\
\text { 2. } & \text { Sekertariat DPRD } \\
\text { 3. } & \text { Dinas Kesehatan } \\
\text { 4. } & \text { Dinas Pendidikan Pemuda dan }\end{array}$ & $\begin{array}{ll}\text { 1. } & \text { Tidak ada } \\
& \text { perubahan } \\
\text { 2. } & \text { Tidak ada } \\
& \text { perubaham }\end{array}$ \\
\hline
\end{tabular}

\begin{tabular}{|c|c|}
\hline 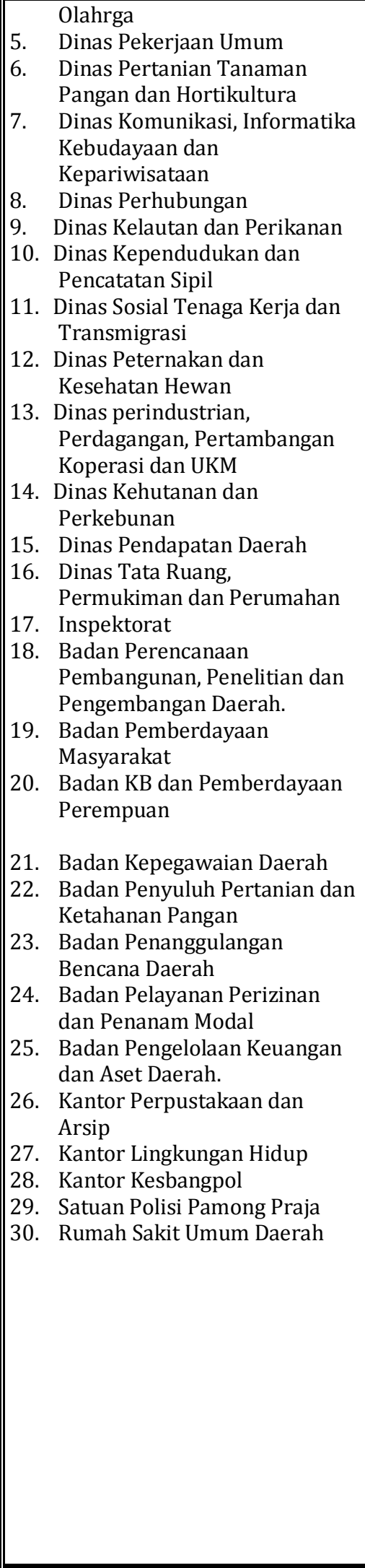 & 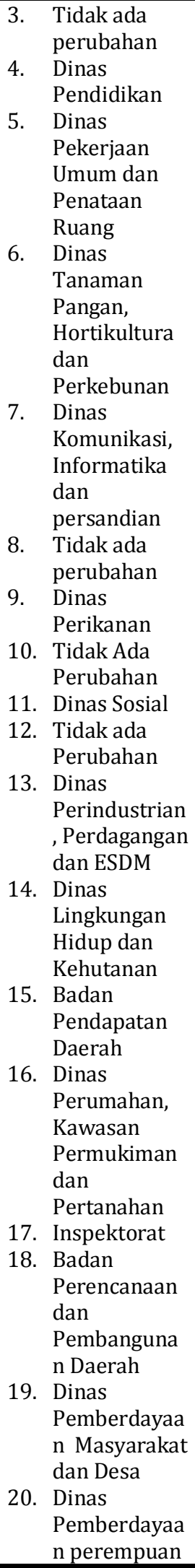 \\
\hline
\end{tabular}




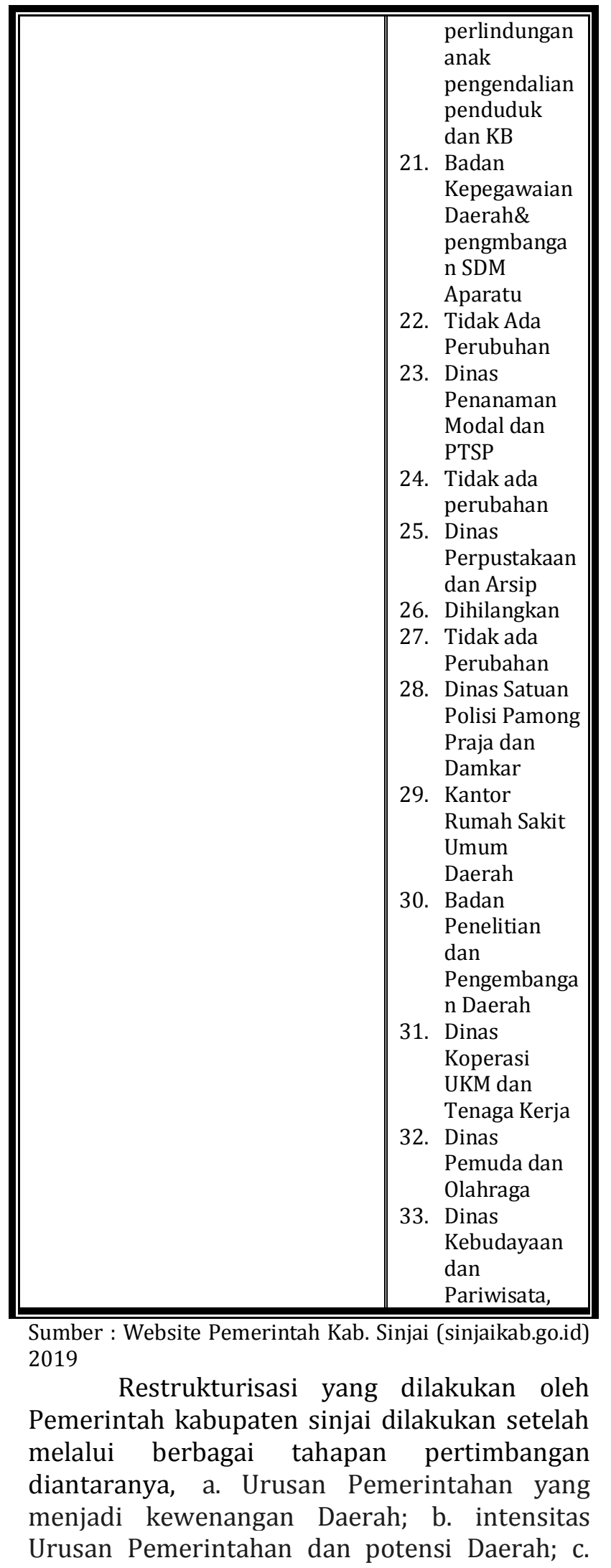

efisiensi; d. efektivitas; e. pembagian habis tugas; f. rentang kendali; g. tata kerja yang jelas; dan h. Fleksibilitas. Susunan perangkat daerah ini juga melalui ditetapkan berdasarkan peraturan daerah, setelah mendapatkan persetujuan dari menteri dalam negeri, setelah menteri dalam negeri menerima usulan perubahan organisasi perangkat daerah, paling lama 15 hari menteri dalam negeri memberi jawaban kepada pemerintah gubernur sebagai wakil pemerintah pusat didaerah untuk menerima usulan keseluruhan atau sebagaian, ataukah dilakukan perbaikan, dalam hal telah melewati perbaikan dari pemerintah daerah maka diundangkan peraturan daerah tersebut menjadi ketetapan susunan organisasi perangkat daerah. Berdasarkan penjelasan dari informan Adijelaskan :

"Penyusunan OPD ini perdebatannya sangat panjang karena banyak aspek yang harus kami pertimbangkan bersama pemerintah diantaranya aspek efektivitas dan efesiensi, kita tidak mau OPD yang lahir nantinya tidak berkesesuaian dengan kebutuhan masyarakat, makanya banyak aspek yang harus dibicarakan sebelum diusulkan kepemerintah, jumlah jabatan yang akan berubah tentu berpengaruh kepada karir ASN, dan faktor ini yang paling menyita pemikiran karena kita tidak ingin ada ASN yang karirnya terhambat karena adanya perubahan ini, kesimpulannya pemerintah dan legislatif di Kabupaten Sinjai telah melakukan sesuai dengan prosedur dan kita mengajukan yang terbaik (21 maret 2019, kab Sinjai)

Dari keterangan ini diketahui bahwa proses pengusulan nomenklatur organisasi perangkat daerah di kabupaten sinjai melalui diskusi yang cukup panjang antara lembaga legislatif dan eksekutif, proses ini terjadi sebagai upaya DPRD kabupaten Sinjai untuk memastikan bahwa nomenklatur perangkat daerah yang akan ditetapkan benar-benar akan sesuai dengan kebutuhan daerah dan masyarakat.

\section{B. Tahapan Penyusunan Organisasi Perangkat Daerah.}

1. Konsultasi Teknis Pada awal penetapan PP 18 Tahun 2016 Tentang perangkat daerah, diwarnai 
berbagai kesimpangsiuran mengenai perubahan bentuk seperti apa saja yang dikehendaki peraturan tersebut, Pada tahap kondisi ini mengakibatkan DaerahDaerah berupaya mencari pola sendiri baik melalui inisiatif maupun konsultasi langsung ke instansi terkait. Dalam konteks ini, Kabupaten Sinjai melalui Bagian Organisasi Sekretariat Daerah Kabupaten Sinjai sebagai Leading sektor mengambil inisiatif untuk melakukan kegiatan konsultatif kepada Pemerintah Pusat, bahkan ada kecenderungan pemikiran serta penilaian bahwa pelaksanaan Otonomi Daerah, khususnya menyangkut penataan organisasi perangkat daerah seolah-olah menjadi kewenangan BagianOrganisasi. Kecenderungan pemikiran semacam ini ditandai dengan pelaksanaan kegiatan rapat maupun seminar-seminar baik pada tingkat Departemen maupun tingkat Provinsi yang selalu melibatkan Bagian Organisasi pada Sekretariat Daerah Kabupaten/Kota.Oleh karena itu, tidak mengherankan apabila draft penyusunan struktur organisasi Pemerintah (Perangkat Daerah) Kabupaten Sinjai sangat diwarnai peran Bagian Organisasi Sekretariat Daerah, konsultasi teknisi dilakukan oleh pmerintah kabupaten Sinjai dalam rangka mendapatkan informasi mengenai subtansi perubahan organisasi perangkat daerah menurut PP 18 Tahun 2016. Hal ini diketahui berdasarkan informasi yang diperoleh dari AI, sebagai berikut :

"Informasi yang kami dengar bahwa ada aturan baru yang diterbitkan oleh pemerintah pusat agar dilakukan perubahan susunan OPD, meski pun telah diketahui bahwa yang dimaksud adalah PP 18 Tahun 2016, namun secara detail masih belum bisa dipastikan arah perubahan dan tahapannya seperti apa, sehingga waktu itu sekertariat daerah mengirim orang untuk berkonsultasi ditingkat provinsi dan pusat. Tujuan dari konsultasi itu tentunya untuk memetakan langkah-langkah apa yang seharusnya ditempuh untuk menindak lanjuti" (21 maret 2019, kab Sinjai)

Informasi ini dapat diartikan bahwa meskipun pemerintah daerah telah mengetahui akan adanya perubahan nomenklatur OPD namun secara teknis mereka belum memahami apa arah orientasi dari perubahan itu sehinggatahapan konsultasi teknis kepada pemerintah provinsi dan pemerintah pusat menjadi langkah awal dalam proses penyusunan nomenklatur organisasi perangkat daerah.

2. Pembentukan Tim Penataan Kelembagaan

Langkah-langkah penyusunan struktur organisasi pemerintah sebagai suatu proses yang dilakukan oleh Tim Penataan Kelembagaan Perangkat Daerah di Kabupaten Sinjai, dimaknai kedalam dimensi formal. Dalam konteks ini, penyusunan struktur organisasi pemerintah dipahami sebagai suatu tahapan yang harus dilalui dalam perumusan kebijakan, dengan prosedur dan mekanisme kerja yang telah ditetapkan berdasarkan peraturan perundang-undangan. Semua tahapan atau langkah penentuan program senantiasa mencerminkan adanya tawar menawar (bargaining posisition) diantara mereka yang berkepentingan dan terlihat dalam kegiatan penyusunan struktur organisasi perangkat daerah yang antara lain tercermin dalam penentuan pelaksanaan tugas tim penataan kelembagaan perangkat daerahsempat di warnai dengan beda pandangan antara pejabat yang terlibat dalam tim penataan menyangkut siapa diantara keduanya yang paling berhak menjadi koordinator dan menjadi 
penanggung jawab pelaksanaan tugas tim penataan kelembagaan perangkat daerah ini.

Keberadaan Tim penataan Kelembagaan Perangkat Daerah memegang peranan penting dalam proses penyusunan struktur organisasi perangkat daerah, dalam artian tim ini pada tahap awal diharapkan mampu untuk melakukan pengenalan masalah dan diagnosa organisasional sebagaimana dikemukakan oleh Nimran (2001) bahwa proses penyusunan struktur organisasi harus dimulai dengan adanya pengenalan masalah dan diagnosis terhadap kondisi organisasi agar dapat diketahui dengan jelas kondisi organisasi, yang akan dikembangkan atau ditata serta untuk diketahui pula permasalahan yang dihadapi dalam proses penyusunan struktur organisasi Pemerintah (perangkat daerah) dimaksud. Sehingga tidak mengherankan apabila penyusunan struktur organisasi pemerintah (perangkat daerah) KabupatenSinjai,masih ditemukan ada beberapa permasalahan yang secara umum dapat disimpulkan :

a. Perubahan yang dilaksanakan masih mengabaikan tahap partisipasi dari setiap pegawai dan komponen lainnya dalam organisasi Pemerintah Kabupaten Sinjai, sehingga input dari unsur-unsur tersebut tidak terakomodir dalam proses penataan organisasi Pemerintah Kabupaten sinjai. Lebih lanjut dalam penyusunan organisasi diharapkan Peran serta seluruh komponen organisasi dalam pelaksanaan proses penyusunan struktur organisasi dimana partisipasi ini akan sangat berpengaruh terhadap hasil akhir penyusunan struktur tersebut. Sesuai pendapat Emitai Etzioni (1964).

b. Proses penyusunan Struktur Organisasi Pemerintah Kabupaten Sinjai masih melibatkan lingkungan terbatas dari para pelaksana yang seharusnya terkait dengan proses tersebut dimana hal ini menyebabkan hasil akhir (output) dari penyusunan struktur organisasi tersebut tidak dapat memberikan manfaat yang optimal bagi pencapaian tujuan-tujuan penyusunan struktur organisasi, khususnya dari aspek peningkatan kinerja, baik secara individual maupun secara keseluruhan.

Ditinjau dari aspek lain, misalnya nomenklatur organisasi terdapat adanya beberapa satuan organisasi yang mempunyai nama hampir sama. Secara sepintas, dapat dikatakan bahwa kesamaan atau kemiripan nama pada dua unit kerja tersebut, menyiratkan adanya kesamaan atau keparalelan dan fungsinya. Dengan kata lain, pada struktur organisasi perangkat daerah ini, masih terdapat fungsi-fungsi yang bersifat "redundant" dan mengarah pada duplikasi fungsi. Juga dalam hal penempatan pegawainya (pengisian jabatan) belum sesuai dengan salah satu prinsip professional.

\section{Kesimpulan}

Kegiatan penataan kelembagaan pada hakikatnya berkaitan dengan masalah desain organisasi yang menurut Edgar Huse (1985) dirumuskan sebagai "kegiatan membagi-bagi tugas kedalam group kerja atau departemen, kemudian mengkoordinasikan group-gruop terpisah tersebut dengan tujuan untuk mencapai efektifitas organisasi secara umum yang mencakup strategi atau sasaran keputusan dan mekanisme pengintegrasian setiap anggota kedalam organisasi". Dengan demikian restrukturisasi organisasi diarahkan untuk mencapai efektifitas, yang menurut Simon (1976 : 179) dinyatakan bahwa "Kriterium efisiensi mengharuskan adanya pilihan antar alternatif-alternatif yang menghasilkan hasil terbesar dalam penggunaan sumber-sumber daya yang langka, guna mencapai tujuan apapun juga ingin di raih oleh organisasi yang bersangkutan. 
Restrukturisasi organisasi pemerintah daerah dikabupaten sinjai telah dilakukan sesuai dengan esensi mengingat pertimbangan bahwa misi pemerintahan untuk memajukan masyarakat, hanya dapat dijalankan dan dicapai jika di dalam organisasi pemerintahan itu sendiri berlangsung mekanisme sistem manejemen yang efektif, efisien dan inovatif (Rasyid,1997:121). Bertitik tolak dari asumsi ini dapat dikatakan bahwa restrukturisasi organisasi di kabupaten Sinjai merupakan upaya untuk mendorong organisasi pemerintah daerah tampil efsien, efektif dan inovatif., meskipun masih terdapat beberapa kekurang dalam penyusunannya. Oleh karena itulah pemerintah daerah di kabupaten sinjai dalam rangka penyusunan organisasi perangkat daerah yang baru ini dikembangkan suatu pendekatan "miskin struktur, kaya fungsi", dapat juga dikatakan sebagai organisasi yang ramping tetapi memiliki fungsi yang besar.

\section{DAFTAR PUSTAKA}

A Etzioni. (1964). Modern Organizations. Englewood: Pretince Hall.

Bennis,Warren dan Mische, Michael, 1995, Organisasi Abad 21 (Reinventing melalui Reengineering), Terjemahan ; Irma Andriani Rachmayanti, PT. Pustaka

Bernard, A. 2010. Asthma and swimming: weighing the benefits and the risks. Journal De Pediatria.

Cahayani, Ati. 2009. Strategi Kebijakan Manajemen Sumber Daya Manusia. Jakarta: Indeks.

Hammer, Michael dan James Champy, 1995, Rekayasa Ulang Perusahaan, Edisi. Kedua, Terjemahan Marcus Pritimindo Widodo, PT Gramedia Pustaka

Lubis, Hari. S.B. dan Martani Husaini. 1987. Teori Organisasi (Suatu Pendekatan. Makro). Jakarta
Kaho, Josef riwu. 1988. Prospek Otonomi di Negara Indonesia. Jakarta: PT. Raja Grafindo Persada

Nimran, Umar. 1997. Perilaku Organisasi. Edisi Revisi. Surabaya: Citra Media

Publication Information Edisi 1. Jakarta: Lembaga Administrasi. Negara (1998)

Sedarmayanti, 2010, Sumber Daya Manusia dan Produktivitas Kerja, cetakan kedua, penerbit: Mandar Maju

Robbins, P. Stephen. (2001). Perilaku Organisasi.Jjilid 1. Edisi Delapan

Rasyid.(1997). Makna Pemerintahan Tinjauan Dari Segi Etika dan. Kepemimpinan, Watampone, Jakarta

Suradinata, Ermaya. 1996. Manajemen Pemerintahan dan Otonomi Daerah.Ramadan. Bandung

Simon, Herbert.(1960). Decision Making and Organizational Design. In D.S. Pugh

Sarundajang, 2001, Arus Balik Kekuasaan Pusat ke Daerah, cetakan kesatu,. Jakarta: Erlangga

Thoha Miftah, 1991, Beberapa Aspek Kebijaksanaan Birokrasi, Widya. Mandala, Jogjakarta

Wexley, Kenneth N \& Gary A Yukl.(2005). Perilaku Organisasi dan Psikologi.Personalia.

Waldo, Dwight. 1955. The study of public administration. University of Virginia: Doubleday

Peraturan Pemerintah Nomor 8 Tahun 2016Tentang Perangkat Daerah

Peraturan Pemerintah Nomor 84 Tahun 2000 tentang Perangkat Daerah

Portal Info Publik 30/9/2016 diakses Tanggal 08 Maret 2018 